\title{
Keratin, Type I Cytoskeletal 17
}

National Cancer Institute

\section{Source}

National Cancer Institute. Keratin, Type I Cytoskeletal 17. NCI Thesaurus. Code C105980.

Keratin, type I cytoskeletal 17 (432 aa, $\sim 48 \mathrm{kDa}$ ) is encoded by the human KRT 17 gene.

This protein plays a role in the development of hair follicles and other skin appendages. 